\title{
INTERNALISASI NILAI-NILAI TAUHID DALAM KESEHATAN MENTAL
}

\author{
Kastolani \\ Mahasiswa Program Doktoral Universitas Kebangsaan Malaysia \\ olano2008@yahoo.co.id
}

\begin{abstract}
For a Muslim, the most important and foremost to reach a healthy mental is to establish, strengthen, and establish the belief and unity of God that exists within him. Because, with a strong, or solid, and steady belief and unity of God, his soul will always be stable, his mind remains calm, and his emotion is under control. The role of unity of God gives calmness and serenity of soul that at least consists of five things; (a) Feeling like to be loved and cherished which is needed by every person in life and existence. (b) Feeling safety is every person's needs within him physically and mentally. (c) Self esteem sense means everyone has self esteem in order to be respected by others. (d) Curiosity or recognizing something, where someone has curiosity instinct. (e) Sense of being successful, everyone wants his life to be successful that will bring happiness.
\end{abstract}

Keywords: Unity of God, Health, Mental

\begin{abstract}
Abstrak
Bagi seorang muslim, usaha yang paling penting dan utama untuk menuju mental yang sehat adalah memantapkan, menguatkan, dan mengokohkan akidah atau tauhid yang ada dalam dirinya. Sebab, dengan akidah atau tauhid yang kuat, kokoh, dan mantap, jiwanya akan selalu stabil, pikirannya tetap tenang, dan emosinya terkendali. Peranan tauhid memberikan ketenangan dan ketenteraman jiwa setidaknya ada lima hal yaitu; (a) Perasaan ingin dikasihi dan disayangi merupakan hal yang sangat dibutuhkan oleh setiap insan dalam hidup dan kehidupannya. (b) Perasaan aman merupakan kebutuhan setiap orang dalam dirinya, baik lahir maupun batin. (c) Rasa harga diri artinya setiap orang memiliki, agar dirinya dihargai orang lain. (d) Rasa ingin tahu atau mengenal sesuatu, seseorang mempunyai naluri ingin tahu. (e) Rasa ingin sukses, setiap orang ingin dalam kehidupannya mengalami keberhasilan yang akan membawa kebahagiaan.
\end{abstract}

Kata Kunci: Tauhid, Kesehatan, Mental 


\section{Pendahuluan}

Dewasa ini negara dan bangsa Indonesia sedang membangun untuk mewujudkan cita-cita suatu masyarakat yang adil makmur. Salah satu usaha untuk mewujudkan cita-cita tersebut adalah melakukan proses modernisasi di berbagai bidang kehidupan, termasuk dibidang teknologi dan ilmu pengetahuan. Namun, ternyata modernisasi yang diterapkan tersebut tidak semuanya membawa dampak positif bagi kehidupan manusia sendiri, terutama di bidang kesehatan mental.

Persoalan besar yang muncul di tengah-tengah umat manusia sekarang ini adalah keringnya aspek rohani. Kemajuan ilmu pengetahuan dan teknologi, yang didominasi rasionalisme, empirisme, dan positivisme, ternyata membawa manusia kepada kehidupan modern yang bermental sekularis. Mereka menjadi terasingkan dari aspek spiritual yang merupakan kebutuhan rohaninya. Oleh karena itu keadaan kehidupan manusia modern tersebut, sebagaimana digambarkan oleh Syafiq A. Mughni yang mengutif pendapat Seyyed Hossein Nasr dalam bukunya, Antara Tuhan, Manusia dan Alam (1984:135) disebut sebagai The Plight of Modern Man, nestapa orang-orang modern (Mughni, 2001:95).

Manusia modern, orientasi hidupnya lebih tertuju pada pemenuhan kebutuhan aspek eksoteris dibandingkan pemenuhan terhadap kebutuhan aspek esoteris. Sebagai akibatnya orientasi manusia berubah menjadi semakin materialistis, individualistis, dan keringnya aspek spiritualitas. Terjadilah iklim yang makin kompetitif yang pada giliranya melahirkan manusia-manusia buas, kejam, dan tak berprikemanusian seperti dikatakan Thomas Hobbes, sebagaimana disitir oleh Nasruddin Razak, Homo Homini Lupus Bellum Omnium Contra Omnes (manusi menjadi srigala untuk manusia lainya, berperang antara satu dengan lainnya (Razak,1986:19).

Pergeseran nilai sebagaimana diungkapkan di atas, mulai dirasakan dampaknya ketika muncul individu-individu yang gelisah, gundah gulana, rasa sepi yang tak beralasan bahkan sampai pada tingkat keinginan 
untuk bunuh diri. Keadaan ini tentunya sudah menyangkut pada aspek kesehatan mental manusia dalam mengarungi kehidupan yang makin kompleks. Mulailah manusia melirik disiplin ilmu agama dengan segala cabang-cabangnya guna memberikan solusi dalam menyikapi gejolak nafsu manusia yang sudah sampai pada level yang mengkhawatirkan.

Dari semua cabang ilmu kedokteran, maka cabang ilmu kedokteran jiwa (psikiatri) dan kesehatan mental (mental health) yang paling dekat dengan agama. Dalam hal ini fokus kajian yang ada pada ilmu kedokteran jiwa dan kesehatan mental berbicara keadaan kesejahteraan dan kebahagiaan pada diri manusia. Begitu pula agama diajarkan kepada manusia agar mentalnya menjadi sehat (Hawari, 1999:12). Oleh karena itu, konsep tauhid dalam ajaran Islam memiliki fungsi yang signifikan. Tauhid yang merupakan inti dari ajaran Islam adalah suatu kepercayaan. Seseorang yang memiliki jiwa tauhid menurut Nasruddin Razak (1973:50). Ia akan terbebas dari rasa ketakutan dan duka cita dalam kemiskinan harta benda, karena ia merasa yakin bahwa tiap binatang melata di bumi ini telah dijamin rizkinya oleh Allah SWT. Ia menjadi sadar bahwa kewajiban bagi manusia ialah bekerja dan berusaha sambil berdoa, hasilnya di tangan Allah sendiri. Tauhid juga membebaskan manusia dari ambisi yang melampaui batas dalam memperoleh jabatan dan kekuasan. Sebab tauhid menyadarkan manusia bahwa Allah yang dapat mengangkat dan menurunkan seseorang dari kemuliaan dan kehormatan. Allah adalah sumber segala kemuliaan, maka barang siapa siapa yang mencari kemuliaan dan kedudukan harus senantiasa ingat kepada-Nya, karena semuanya itu ada pada sisi Allah SWT.

Bertitik tolak dari keterangan di atas, Dadang Hawari (1999:433) menegaskan bahwa tauhid membebaskan manusia dari perasaan takut akan mati. Tauhid menyadarkan manusia bahwa persoalan mati ada di tangan Allah, dan setiap yang berjiwa pasti mengalami mati. Baginya mati adalah awal kehidupan baru yang sesungguhnya setelah manusia melewati 
kehidupan yang fana ini. Konsekuensinya menumbuhkan semangat jihad seseorang untuk menegakkan yang hak dan menghancurkan yang batil, sekalipun ia harus menyabung nyawa dan mempertaruhkan jiwa raga. Seorang muslim harus memiliki keberanian; berani berpihak kepada kebenaran dan keadilan, berani hidup, juga berani mati demi keagungan Allah SWT.

Tauhid juga membebaskan manusia dari perasaan keluh kesah, bingung menghadapi persoalan hidup dan akan bebas dari rasa putus asa. Dengan tauhid, seorang Muslim memiliki jiwa besar, tidak berjiwa kerdil, memiliki jiwa yang agung dan tenang. Tauhid memberikan kebahagiaan hakiki pada manusia di dunia, dan kebahagian abadi di akherat kelak (Razak, 1986:56).

Oleh karena itu, bimbingan dan pendalaman mengenai makna tauhid sangat penting bagi manusia. Bimbingan dan pendalaman terhadap makna tauhid tersebut akan membantu seseorang untuk senantiasa berikir positif terhadap berbagai kondisi atau kejadian negatif yang sedang menimpanya; jiwa tetap tenang, dan hati menjadi tabah. Keimanan kepada Allah ini kalau benar-benar dihayati dan diamalkan besar manfaatnya bagi kesehatan mental manusia, rasa sejahtera akan dirasakan tidak hanya bagi perorangan, tetapi juga dirasakan bagi keluarga, masyarakat dan bangsa secara keseluruhan (Hawari, 1999:431).

\section{Nilai-nilai Tauhid}

Kata tauhid ialah mengesakan, berasal dari bahasa Arab (wahhadayuwahhidu-tauhidan). Jadi bertauhid artinya mengesakan Tuhan sebagai pencipta semesta alam, yang tidak ada sekutu bagi-Nya dengan keyakinan yang bulat. Pendapat yang sama, bahwa perkataan tauhid berasal dari bahasa arab, masdar dari kata wahhada, yuwahhidu. Secara etimologis, tauhid berarti keesaan, i'tiqad atau keyakinan bahwa Allah SWT adalah esa; tunggal; satu. Pengertian ini sejalan dengan pengertian tauhid yang 
terdapat dalam Kamus Besar Bahasa Indonesia, yaitu keesaan Allah; mentauhidkan berarti 'mengakui keesaan Allah (Kridaklasana, 1989:907).

Secara tradisional dan sederhana, tauhid adalah keyakinan dan kesaksian bahwa tidak ada Tuhan selain Allah. Pernyataan yang tampak negatif ini, sangat singkat, mengandung makna paling agung dan kaya dalam seluruh hazanah Islam. Kadang-kadang seluruh kebudayaan, seluruh peradaban, atau seluruh sejarah dipadatkan dalam satu kalimat yaitu kalimat tauhid (al-Faruqi, 1995:9).

Tauhid mempengaruhi kehidupan manusia, dengan tauhid tidak mungkin seseorang mempunyai pandangan sempit, karena ia percaya kepada yang menciptakan langit dan bumi, pemilik seantero jagat, barat dan timur, pemberi rizki dan pendidik mereka, tidaklah bisa ditemukan di alam ini sesuatu yang ganjil sesudah adanya iman, karena segala sesuatu yang ada di dalamnya adalah milik-Nya. Tidak ada sesuatupun di alam ini yang mampu merintangi dan membatasi rasa cinta-Nya.

Orang yang bertauhid, akan luas pandangannya, tidak suatupun yang menyempitkan dia, sebagaimana tidak ada sesuatupun dari milik Allah yang menjadi sempit. Yang demikian itu tidak mungkin didapat oleh seseorang yang menganut faham ketuhanan yang berbilang, atau yang menganggap Allah SWT mempunyai sifat-sifat seperti manusia yang kurang dan terbatas, atau tidak percaya kepada Allah sama sekali.

Iman kepada kalimat tauhid melahirkan rasa bangga dan harga diri pada manusia, yang tidak dapat dirintangi oieh sesuatu. la mengetahui, bahwa Tuhan yang Maha Esa adalah Pemilik yang hakiki dari segala kekuatan yang ada di alam ini, mengetahui bahwa tidak ada yang memberi manfaat dan mudharat kecuali Dia, mengetahui bahwa tidak ada yang menghidupkan dan mematikan kecuali Dia, dan mengetahui bahwa tidak ada yang memiliki hukum, kekuasaan dan kedaulatan kecuali Dia sendiri.

Ilmu yang yakin ini menjadikan dia tidak berhajat kepada yang lain selain pada Allah, dan mencabut dari dalam hatinya rasa takut kepada 
yang lain dari padaNya. Maka tidaklah ia akan menundukkan kepalanya di hadapan makhluk, tidak merendahkan diri dan mengemis kepadanya dan tidak gentar karena kecongkakan dan kebesarannya. Sifat seperti ini tidak mungkin dimiliki oleh seseorang manusia yang tidak bertauhid.

Salah satu dari pembawaan syirik, kufur dan kemurtadan, ialah bahwa seseorang mau menundukkan kepalanya kepada yang lain selain pada Allah, dan menganggapnya bahwa ia berkuasa untuk memberi manfaat dan mudharat kepadanya. la takut dan menggantungkan harapan kepadanya selain pada Allah SWT.

Bersamaan dengan ini, yaitu bersamaan dengan rasa bangga dan harga diri, adalah iman kepada kalimat tauhid menumbuhkan rasa rendah hati pada diri manusia. Orang yang mengakui, la ilaha illallah tidak mungkin akan menjadi seorang yang congkak dan tidak bersyukur nikmat, dan hampir tidak pernah ia terpedaya oleh kekuatannya dan kecakapannya, karena ia mengetahui dan yakin bahwa hanya Allah yang mengaruniai semua yang ada padanya. Allah SWT berkuasa mencabutnya kembali apabila la menghendakinya (Al-Maududi, 1975:80).

Adapun manusia yang murtad yang tidak percaya kepada adanya zat Allah, maka adalah ia mengingkari nikmat, dan congkak. Apabila memperoleh nikmat yang segera, ia menganggap bahwa nikmat ini adalah buah dari usaha dan kecakapannya. Begitu juga seorang musyrik, menyekutukan Tuhan, berlaku congkak ketika memperoleh sesuatu nikmat keduniaan karena ia menyangka bahwa ia mendapat perhatian dari Tuhan-Tuhannya yang tidak didapat oleh orang lain (Al-Maududi, 1975:81). Orang yang bertauhid mengetahui dengan penuh keyakinan, bahwa tidak ada jalan untuk mencapai keselamatan dan keberuntungan kecuali dengan kesucian jiwa dan amal saleh, karena ia beriman kepada Tuhan yang Maha Kaya dan Maha Adil yang bergantung kepada-Nya segala sesuatu, yang tidak mempunyai hubungan kekeluargaan dengan seseorang dan tidak seorangpun mempunyai campur tangan atau 
pengaruh dalam ketuhanan-Nya.

Adapun orang-orang musyrik dan orang-orang kafir, mereka semata-mata menghabiskan masa hidupnya untuk angan-angan yang palsu. Di antara mereka ada yang berkata; Sesungguhnya anak Allah telah menjadi penebusan dosa-dosa kita kepada Bapanya. Di antara mereka ada yang berkata; Kami adalah putera-putera Allah dan kekasih-kekasihnya, maka tidaklah Ia akan menyiksa kami karena dosa kami. Di antara mereka ada yang berkata; Kami akan meminta syafaat pada sisi Allah kepada pembesar-pembesar kami dan orang-orang yang taqwa daripada kami. Di antara mereka ada yang mempersembahkan nazar-nazar dan kurban-kurban kepada tuhan-tuhan mereka, dan menganggap bahwa dengan demikian mereka telah mendapat izin untuk bekerja sekehendak hatinya.

Kepercayaan yang bobrok ini dan seumpamanya, senantiasa membenamkan orang-orang itu ke dalam lumpur dosa dan maksiat (AlMaududi, 1975:82). Adapun orang-orang yang murtad yang sama sekali tidak percaya bahwa di sana ada Pencipta atau Khaliq di atas mereka, yang akan meminta pertanggungan jawab atas perbuatan-perbuatan mereka dan akan memberikan pembalasan kepada mereka atasnya, jika baik maka pembalasannya baik dan jika buruk maka pembalasannya buruk pula, maka mereka menyangka bahwa mereka merdeka di dunia, tidak terikat dengan sesuatu undang-undang dari atas mereka. Hawa nafsu mereka adalah Tuhan mereka, sedang mereka adalah budak-budaknya. Orang yang percaya kepada kalimat tauhid tidak mudah dihinggapi oleh rasa putus asa dan hilang harapan dalam keadaan bagaimanapun, karena ia beriman kepada yang memiliki langit dan bumi, yang tidak terhingga bilangan nikmat dan karunia-Nya. Iman memberikan ketenteraman yang luar biasa di hatinya dan mengisinya dengan ketenangan dan harapan, meskipun ia dihina di dunia dan diusir dari semua pintu jalan penghidupan. Orang bertauhid senantiasa mencurahkan tenaganya dengan bertawakkal kepada Allah dan meminta pertolongan daripada-Nya dalam segala 
urusan. Ketenangan hati dan ketenteraman jiwa ini, tidak mungkin didapat dengan sesuatu kecuali dengan akidah dan tauhid. Oleh karena orangorang kafir, orang-orang musyrik dan orang-orang, murtad lemah hatinya, sedang mereka bersandar kepada kekuatan-kekuatan yang terbatas, maka alangkah cepatnya dihinggapi oleh rasa putus asa ketika menghadapi kesukaran-kesukaran, yang kadang-kadang membawa mereka kepada bunuh diri. Iman kepada kalimat tauhid mendidik manusia di atas suatu kekuatan yang besar dalam kebulatan tekad, keberanian, kesabaran, ketabahan dan tawakkal, dikala ia menghadapi perkara-perkara besar di dunia, demi untuk mengharapkan keridhaan Allah. Ia mempunyai penuh keyakinan bahwa kekuatan Tuhan yang memiliki langit dan bumi menyokong dari belakangnya dan membimbing tangannya pada tiap-tiap taraf dari taraf-taraf kehidupannya.

Menurut Syekh Muhammad Abduh ilmu tauhid adalah ilmu yang membicarakan tentang wujud Tuhan, sifat-sifat yang mesti ada padaNya, sifat-sifat yang boleh ada pada-Nya, sifat-sifat yang tidak mungkin ada pada-Nya; membicarakan tentang rasul-rasul, untuk menetapkan keutusan mereka, sifat-sifat yang boleh dipertautkan kepada mereka, dan sifat-sifat yang tidak mungkin terdapat pada mereka (Abduh,1979:4).

\section{Makna Kesehatan Mental}

Dari berbagai kepustakaan yang diteliti, peneliti mendapat kesan belum adanya kesepakatan para ahli dalam merumuskan kesehatan mental (mental healt). Hal itu disebabkan antara lain adanya dikotomi karena adanya berbagai sudut pandang dan sistem pendekatan yang berbeda. Dengan tidak adanya kesatuan pendapat dan pandangan tersebut, menimbulkan adanya perbedaan konsep kesehatan mental. Lebih jauh lagi mengakibatkan terjadinya perbedaan implementasi dalam mencapai dan mengusahakan mental yang sehat. Perbedaan itu wajar dan tidak perlu merisaukan, karena sisi lain adanya perbedaan itu justru mem- 
perkaya khasanah ilmu pengetahuan dan memperluas pandangan orang mengenai apa dan bagaimana kesehatan mental (Musnamar, 1992:xiii).

Istilah kesehatan mental mempunyai pengertian yang cukup banyak, karena mental itu sendiri bersifat abstrak sehingga dapat menimbulkan berbagai penafsiran dan definisi-definisi yang berbeda. Karena itu banyak pengertian dan definisi yang diberikan oleh para ahli sebagaimana menurut Zakiah Darajat, bahwa kesehatan mental adalah terhindarnya seseorang dari gejala-gejala ganggunan dan penyakit mental, dapat menyesuaikan diri, dapat memanfaatkan segala potensi dan bakat yang ada semaksimal mungkin dan membawa kepada kebahagiaan bersama, serta tercapainya keharmonisan jiwa dalam hidup (Daradjat, 1982:13). Sedangkan menurut Kartini Kartono, bahwa kesehatan mental adalah bagaimana cara orang memecahkan segenap keruwetan batin manusia yang ditimbulkan oleh macam-macam kesulitan hidup, serta berusaha mendapatkan kebersihan jiwa, dalam pengertian tidak terganggu oleh macam-macam ketegangan, kekalutan dan konflik terbuka serta konflik batin (Kartono, 1989:4). Dari beberapa penjelasan tersebut dapat dipahami bahwa kesehatan mental adalah terwujudnya keharmonisan dan keserasian jiwa yang dapat memecahkan segala macam persoalan, untuk selanjutnya akan memunculkan kebahagiaan.

Berangkat dari definisi kesehatan mental yang berbeda-beda sesuai dengan bidang dan pandangan masing-masing, maka upaya pencapaiannya juga beragam. Kartini Kartono berpendapat ada tiga prinsip pokok untuk mendapatkan kesehatan mental, yaitu; (a) Pemenuhan kebutuhan pokok yaitu setiap individu selalu memiliki dorongan-dorongan dan kebutuhankebutuhan pokok yang bersifat organis (fisik dan psikis) dan yang bersifat sosial. Kebutuhan-kebutuhan dan dorongan-dorongan itu menuntut pemuasan. Timbullah ketegangan-ketegangan dalam usaha pencapaiannya. Ketegangan cenderung menurun jika kebutuhan-kebutuhan terpenuhi, dan cenderung naik/makin banyak, jika mengalami frustasi atau 
hambatan-hambatan. (b) Kepuasan.maksudnya setiap orang menginginkan kepuasan, baik yang bersifat jasmaniah maupun yang bersifat psikis. Dia ingin merasa kenyang, aman terlindung, ingin puas dalam hubungan seksnya, ingin mendapat simpati dan diakui harkatnya. Pendeknya ingin puas disegala bidang, lalu timbullah Sense of Importancy dan Sense of Mastery, kesadaran nilai dirinya dan kesadaran penguasaan yang memberi rasa senang, puas dan bahagia. (c) Posisi dan status sosial artinya setiap individu selalu berusaha mencari posisi sosial dan status sosial dalam lingkungannya. Tiap manusia membutuhkan cinta, kasih, dan simpati. Sebab cinta, kasih, dan simpati menumbuhkan rasa diri aman, assurance, keberanian dan harapan-harapan di masa mendatang. Seseorang menjadi optimis dan bergairah. Karenanya individu-individu yang mengalami gangguan mental, biasanya merasa dirinya tidak aman. Mereka senantiasa dikejar-kejar dan selalu dalam kondisi ketakutan. Dia tidak mempunyai kepercayaan pada diri sendiri dan hari esok, jiwanya senantiasa bimbang dan tidak imbang (Kartono, 1989:30).

Zakiah Darajat berpendapat kehilangan ketentraman batin itu, disebabkan oleh ketidakmampuan menyesuaikan diri, kegagalan, tekanan perasaan, baik yang terjadi dirumah tangga, di kantor ataupun dalam masyarakat. Maka sebagai upayanya Zakiah Daradjat mengutip firman Allah SWT surat ar-Radu ayat 28 yang artinya, ketahuilah bahwa dengan mengingat Allah itu hati menjadi tentram.

Dalam ayat di atas dinyatakan bahwa dzikir itu bisa membentuk hati manusia untuk mencapai ketentraman. Dzikir berasal dari kata dzakara artinya mengingat, memperhatikan sambil mengambil pelajaran, mengenal atau mengerti. Biasanya perilaku dzikr diperlihatkan orang hanya dalam bentuk renungan sambil duduk berkomat-kamit. Al-Quran memberi petunjuk bahwa dzikir itu bukan hanya ekspresi daya ingat yang ditampilkan dengan komat-kamitnya lidah sambil duduk merenung, tetapi lebih dari itu, dzikir bersifat implementatif dalam berbagai variasi 
yang aktif dan kreatif (Daradjat, 1982:104).

Al-Quran menjelaskan dzikir berarti membangkitkan daya ingatan dengan mengingat Allah (dzikrullah), hati orang-orang beriman menjadi tenang. Ketahuilah dengan mengingat Allah, hati menjadi tenang. Dzikir berarti pula ingat akan hukum-hukum Allah; sesungguhnya Allah menyuruh (kamu) berlaku adil dan berbuat kebajikan, memberikan kaum kerabat, dan Allah melarang perbuatan keji, kemungkaran dan permusuhan, dan memberi pengajaran kepada kamu agar kamu dzikir dapat mengambil pelajaran (Daradjat, 1982:104).

Dzikir juga mengambil pelajaran atau peringatan, Allah memberikan hikmah kepada orang atau siapa saja yang dikehendaki-Nya. Barang siapa yang diberi hikmah, sungguh telah diberi kebajikan yang banyak dan tak ada yang dapat mengambil pelajaran kecuali orang-orang yang berakal (ulul albab) (Daradjat, 1982:104).

Hasan Langgulung mensyaratkan, bahwa untuk mencapai kebahagiaan ada dua syarat, yaitu iman dan amal. Iman adalah kepercayaan kepada Allah, Rasul-rasul, Malaikat-malaikat, Kitab-kitab, hari kiamat, dan qodlo qodhar, ini semua berkaitan dengan kebahagiaan akherat. Adapun syarat kedua adalah amal, yakni perbuatan, tindakan, tingkah laku termasuk yang lahir dan yang batin, yang nampak dan tidak tampak, amal jasmaniah ataupun amal rohaniah.

Amal itu ada dua macam, amal ibadah, devational acts yaitu amal yang khusus dikerjakan untuk membersihkan jiwa, untuk kebahagiaan jiwa itu sendiri. Adapun jenis amal yang kedua ialah yang berkaitan dengan manusia lain, seperti amal dalam perekonomian, kekeluargaan, warisan, hubungan kenegaraan, politik, pendidikan, sosial, kebudayaan dan lain-lain (Langgulung, 1986:398).

Kedua hal tersebut, iman dan amal akan mendapat balasan dari Allah SWT. sebagaimana firman-Nya, dalam surat al-Baqoroh ayat 25 , yang artinya, dan sampaikan berita gembira kepada mereka yang 
beriman dan berbuat baik, bahwa bagi mereka disediakan surga-surga yang mengalir sungai-sungai di dalamnya.

Dalam sidang WHO pada Tahun 1959 di Geneva telah berhasil merumuskan kriteria jiwa yang sehat. Seseorang dikatakan mempunyai jiwa yang sehat apabila yang bersangkutan itu; (a) Dapat menyesuaikan diri secara konstruktif pada kenyataan, meskipun kenyataan itu buruk baginya. (b) Memperoleh kepuasan dari hasil jerih payah usahanya. (c) Merasa lebih puas memberi dari pada menerima. (d) Secara relatif bebas dari rasa tegang (stress), cemas dan depresi. (e) Berhubungan dengan orang lain secara tolong menolong dan saling memuaskan (Hawari, 2002:13).

Menurut Hanna Djumhana Bastaman, kriteria sehat mental antara lain bebas dari gangguan dan penyakit kejiwaan, mampu menyesuaikan diri dalam pergaulan sosial dan menjaga kelestarian lingkungan sekitar, serta merealisasi berbagai potensi dirinya (Bastaman, 1995:6). Sebuah pembangunan tidak hanya ditekankan pada pembangunan fisik saja, melainkan juga pembangunan mental spiritual tidak dapat di lepaskan begitu saja, karena kedua-duanya harus terjadi keseimbangan yang akan membawa kepada timbulnya transformasi sosial yang akan berpengaruh kepada nilai-nilai kehidupan. Apabila transformasi sosial yang terjadi mengarah kepada penurunan nilai-nilai moralitas, maka akan membawa dampak yang buruk terhadap perkembangan mental.

Kesehatan mental harus sejak dini diperhatikan, terutama pada anak-anak demi kelangsungan hidup selanjutnya agar tidak mengalami gangguan pada mentalnya. Dalam hal ini Balnadi Sutadipura mengemukakan ciri-ciri mental yang sehat, yaitu; (a) Memiliki pertimbangan objektif, yaitu kemampuan untuk memandang segala macam kejadian secara jujur dan teliti seadanya tanpa menambah atau menguranginya. Kemampuan ini disebut juga rasionalitas atau fikiran sehat. (b) Autonomy, yaitu kemampuan seseorang untuk memperlakukan kejadian sehari-hari 
atas pertimbangannya sendiri yang mandiri dan dewasa, seperti; inisiatif, self direction, emosional independence dan sebagainya.

Kesehatan mental yang tidak lepas dari faktor kepribadian ini dalam perkembangan manusia mempunyai fase-fase tertentu, sedangkan tingkat perkembangan pribadi akan dianggap wajar sesuai dengan tingkat perkembangan pada umumnya. Apabila dalam perkembangan selanjutnya mengalami perkembangan yang wajar sesuai dengan berfungsinya mekanisme kerja organ-organ tubuh atau fisik dan psikisnya tidak mengalami gangguan, maka kesehatan mental atau mentalnya pun tidak akan mengalami penyimpangan berarti. Kalau sudah demikian kebahagiaan hidup mulai dapat dirasakan karena mampu menyesuaikan diri dalam seluruh interaksi dan aktivitas di lingkungan dalam arti luas, baik dalam keluarga, masyarakat maupun dalam lingkungan sekolah.

Kemampuan merasakan kebahagiaan hidup merupakan ciri dari kesehatan mental. Akan tetapi ciri-ciri kesehatan mental pada dasarnya dapat dilihat dari faktor-faktor atau komponen-komponen yang mempengaruhi kesehatan mental secara keseluruhan, yaitu perasaan, fikiran, kelakuan dan kesehatan. Keempat faktor atau komponen tersebut apabila tidak ada gejala umum yang menunjukkan kurang sehat, maka sudah berarti kesehatan mentalnya terjaga dan gangguan mental yang muncul berkisar dari empat faktor tersebut.

Untuk lebih jelasnya ada beberapa contoh seperti berikut (a) Perasaan, dalam perasaan yang selamanya terganggu (tertekan), tidak tenteram, rasa gelisah tidak menentu apa yang digelisahkan dan tidak bisa pula mengatasinya, selamanya berperasaan takut yang tidak masuk akal atau tidak jelas apa yang ditakutinya itu, selamanya merasa iri, rasa sombong, suka bergantung kepada orang lain, tidak mau bertanggung jawab dan lain-lain. (b) Pikiran, dapat memiliki peranan penting dalam menggangu kesehatan mental anak, demikian pula mental dapat mempengaruhi pikiran, misalnya, anak-anak menjadi bodoh di sekolah, 
menjadi pemalas, pelupa, suka membolos, tidak bisa konsentrasi. (c) Kelakuan, terganggunya kesehatan mental biasanya ditandai dengan senangnya berkelakuan tidak baik, seperti; kenakalan, keras kepala, suka berdusta, menipu, menyeleweng, mencuri, menyiksa orang lain dan lainlain. Perbuatan ini selalu menyebabkan orang menderita, haknya teraniaya, dan sebagainya. (d) Kesehatan, secara jasmaniah dapat terganggu pula kesehatannya, hal ini dapat juga terjadi bukan karena fisiknya langsung, akan tetapi perasaannya akibat dari mental yang tidak tenteram.

Dalam perawatan mental, psiko-terapi ternyata yang menjadi pengendali utama dalam setiap tindakan dan perbuatan seseorang bukanlah akal pikiran semata-mata, akan tetapi yang lebih penting dan kadang-kadang sangat menentukan adalah perasaan. Telah terbukti bahwa tidak selamanya perasaan tunduk kepada pikiran, bahkan sering terjadi sebaliknya, pikiran tunduk kepada perasaan. Dapat dikatakan bahwa keharmonisan antara pikiran dan perasaanlah yang membuat tindakan seseorang tampak matang dan wajar (Darajat, 1982:13). Sehingga dapat dikatakan bahwa tujuan hygiene mental atau kesehatan mental adalah mencegah timbulnya gangguan mental dan gangguan emosi, mengurangi atau menyembuhkan penyakit mental serta memajukan mental.

Menjaga hubungan sosial akan dapat mewujudkan tercapainya tujuan masyarakat, dan membawa kepada tercapainya tujuan-tujuan perseorangan sekaligus. Kita tidak dapat menganggap bahwa kesehatan mental hanya sekadar usaha untuk mencapai kebahagiaan masyarakat, karena kebahagiaan masyarakat itu tidak akan menimbulkan kebahagiaan dan kemampuan individu secara otomatis, kecuali jika kita masukkan dalam pertimbangan kita, kurang bahagia dan kurang menyentuh aspek individu, dengan sendirinya akan mengurangi kebahagiaan dan kemampuan social.

Dari uraian di atas dapat lebih difokuskan, bahwa tujuan mental hygiene atau kesehatan mental adalah tercapainya kebahagiaan secara 
individu maupun kebahagiaan masyarakat pada umumnya. Dalam Islam pengembangan kesehatan mental terintegrasi dalam pengembangan pribadi pada umumnya, dalam artian kondisi kejiwaan yang sehat merupakan hasil sampingan dari kondisi pribadi yang matang secara emosional, intelektual dan sosial, serta terutama matang pula ketuhanan dan ketaqwaan kepada Tuhan Yang Maha Esa.

Dengan demikian dalam Islam dinyatakan betapa pentingnya pengembangan pribadi-pribadi meraih kualitas 'insan paripurna', yang otaknya sarat dengan ilmu yang bermanfaat, bersemayam dalam kalbunya iman dan taqwa kepada Tuhan. Sikap dan tingkah lakunya benar-benar merefleksikan nilai-nilai keislaman yang mantap dan teguh. Otaknya terpuji dan bimbingannya terhadap masyarakat membuahkan ketuhanan, rasa kesatuan, kemandirian, semangat kerja tinggi, kedamaian dan kasih sayang. Kesan demikian pasti mentalnya pun sehat. Suatu tipe manusia ideal dengan kualitas-kualitasnya mungkin sulit dicapai. Tetapi dapat dihampiri melalui berbagai upaya yang dilakukan secara sadar, aktif dan terencana sesuai dengan prinsip yang terungkap dalam firman Allah SWT dalam surat ar-Ra'du ayat 11 yang artinya, sesungguhnya Allah tidak mengubah suatu kaum sehingga mereka mengubah keadaan yang ada pada diri mereka sendiri.

Ayat ini menunjukkan bahwa Islam mengakui kebebasan berkehendak dan menghargai pilihan pribadi untuk menentukan apa yang terbaik baginya. Dalam hal ini manusia diberi kebebasan untuk secara sadar aktif melakukan lebih dahulu segala upaya untuk meningkatkan diri dan merubah nasib sendiri dan barulah setelah itu hidayah Allah akan tercurah padanya. Sudah tentu upaya-upaya dapat meraih hidayah Allah SWT itu harus sesuai dan berdasarkan al-Quran dan al-Hadits. Selain itu dalam Islam kebebasan bukan merupakan kebebasan tak terbatas, karena niat, tujuan, dan cara-caranya harus selalu sesuai dengan nilainilai agama dan norma-norma yang berlaku. 


\section{Relasi Bertauhid dan Kesehatan Mental}

Dalam masyarakat, istilah mental sering digunakan sebagai ganti dari perkataan kepribadian. Ini berarti, mental sama dengan keseluruhan kualitas diri seseorang (Ramayulis, 2002:124). Dewasa ini masalah kesehatan mental cukup mendapat perhatian, terutama oleh para ahli ilmu pengetahuan, lebih khusus lagi dikalangan para ahli perawatan mental. Tidak jarang kita mendengar kasus penyakit yang-secara teoritisdengan obat tertentu dapat disembuhkan, namun setelah ditunggu sekian lama kesembuhan yang diharapkan itu tidak kunjung tiba. Kalaupun ada kesembuhan, sifatnya hanya sementara. Penyembuhan tuntas baru berhasil setelah pasien tersebut mendapat perawatan ahli jiwa melalui konsultasi dan memenuhi petunjuknya. (Jalaluddin, 2004:250)

Pernyataan 'dalam raga yang sehat terdapat jiwa yang sehat, tidak seluruhnya dapat diterima. Yang diterima justru sebaliknya, 'dalam jiwa yang sehat terdapat raga yang sehat'. Memang antara jasmani dan rohani terdapat hubungan timbal balik yang saling mempengaruhi. Terminologi mental mempunyai keterkaitan dengan hal-hal yang bersifat batin. Karena itu, mengetahui kesehatan mental sebenarnya termasuk hal yang bersifat relatif. Yang dapat diketahui hanyalah seberapa jauh jarak kesehatan mental seseorang dengan kesehatan mental manusia pada umumnya, yang dianggap normal.

Dalam usaha untuk memenuhi keinginan atau kebutuhan hidup, seseorang kadang-kadang mendapat halangan dan rintangan, bahkan mengalami jalan buntu. Kondisi ini akan mengganggu ketenangan, bahkan dapat mengganggu keseimbangan mentalnya. Kegagalan dalam usaha untuk memenuhi keinginan atau kebutuhan itu ada yang berasal dan dalam dirinya, yaitu kegagalan penyesuaian dalam dirinya, dan ada pula yang berasal dari luar dirinya (Ahyadi, 1995:212).

Dalam kehidupan sehari-hari, kebutuhan dan keinginan manusia beraneka ragam, sesuai dengan tingkat kehidupan, lingkungan, dan tingkat 
rasa kepuasannya. Di samping itu, ada kebutuhan yang dirasakan harus ada pada setiap orang, yaitu rasa ingin disayang, rasa aman, harga diri, ingin tahu, dan ingin sukses. Apabila salah satu kebutuhan yang dirasakan harus ada itu tidak terpenuhi secara wajar akan timbul rasa tidak senang pada diri seseorang. Kadar ketidaksenangan itu sesuai dengan keadaan jiwanya, lingkungannya, dan banyak sedikitnya kebutuhan tersebut terpenuhi. Ketidaksenangan inilah yang dapat menimbulkan kecemasan dan mengganggu keseimbangan mental seseorang (Hawari, 2002:140).

Seorang pedagangyang mengalamikegagalan dalam perniagaannya atau pegawai yang gagal menduduki jabatan, tentu merasa tidak senang dan kecewa. Kekecewaan tersebut akan mengganggu keseimbangan mental. Makin tinggi tingkat kekecewaan itu makin berat gangguan keseimbangan mental tersebut. Hal ini dapat membawanya melakukan apa saja demi menghilangkan kekecewaan tersebut, bahkan ada yang bunuh diri, jika mentalnya tidak sehat dan kuat. Tetapi, jika mentalnya atau jiwanya sehat dan kuat, apa pun masalah yang dihadapinya, ia akan selalu tenang dan mampu mengendalikan diri. Kegagalan baginya bukan membuatnya putus asa apalagi bunuh diri, tetapi menjadi pelajaran berharga dan memacu dirinya untuk lebih giat dan gigih berusaha mencapai sukses. Karena itu, kesehatan mental sangat penting bagi seseorang agar ia dapat menghadapi dan mengatasi problema kehidupan dengan jiwa yang tenang, tenteram, dan damai.

Bagi seorang muslim, usaha yang paling penting dan utama untuk menuju mental yang sehat adalah memantapkan, menguatkan, dan mengokohkan akidah (tauhid) yang ada dalam dirinya. Sebab, dengan akidah (tauhid) yang kuat, kokoh, dan mantap, jiwanya akan selalu stabil, pikirannya tetap tenang, dan emosinya terkendali. Untuk memperoleh akidah yang kuat dan kokoh tersebut, mau tidak mau, seseorang harus memperoleh pendidikan akidah yang baik, intensif, dan benar. Sebagaimana diketahui, pendidikan akidah yang paling utama adalah di 
dalam lingkungan keluarga, baru kemudian di sekolah dan di masyarakat. Bagaimana peranan akidah Islamiah memberikan ketenangan dan ketenteraman jiwa dalam hubungannya dengan pemenuhan kebutuhan manusia yang dirasakan harus ada pada setiap orang, dapat dilihat pada uraian berikut ini (Romli, 2003:58).

Pertama, perasaan ingin dikasihi dan disayangi merupakan hal yang sangat dibutuhkan oleh setiap insan dalam hidup dan kehidupannya. Bentuk perasaan yang diinginkan tersebut bermacam-macam seperti perhatian, bantuan atau pertolongan dan penghormatan dari pihak lain, misalnya, saran atau pendapatnya selalu menjaditumpuan perhatian orang, dalam kesulitan atau kesusahan ia mendapat bantuan dan pertolongan, jika ia bekerja di kantor ia disegani bawahan dan diperhatikan atasan, dan sebagainya. Kalau hal-hal tersebut dapat terpenuhi, ia sangat senang dan gembira. Tapi, jika terjadi sebaliknya, keseimbangan mentalnya akan terganggu. Dalam dirinya mungkin muncul perasaan yang bukanbukan seperti rasa dibenci, tidak disenangi orang, dimusuhi, atau rasa dikucilkan. Apabila perasaan demikian sangat mendalam, mentalnya menjadi sakit. Penyakit ini membawa pula kepada penyakit tubuh atau raganya. Penyakit mental ini bisa juga membawa sikap atau tindakan yang negatif yang justru makin merendahkan derajat dan martabatnya di tengah-tengah masyarakat, seperti marah-marah tanpa arah dan sebab yang jelas, berusaha menyakiti orang lain yang dianggap tidak perduli atau memperhatikannya dengan berbagai cara, dan bersikap tidak sopan.

Dalam akidah Islam diajarkan bahwa Allah SWT sangat memperhatikan hamba-hamba-Nya, Allah Maha Pengasih dan Maha Penyayang. Hamba-Nya tidak pernah ditinggalkan, apalagi jika hamba itu selalu berusaha mendekatkan diri kepada-Nya dengan melaksanakan ibadah dan kewajiban-kewajibannya. Akidah Islamiah juga mengajarkan bahwa segala sesuatu kembali kepada Allah. Pujian, cinta kasih, perhatian, dan sebagainya adalah untuk Allah dan karena Allah. Biarpun 
seluruh umat manusia tidak ada yang memperhatikan, memperdulikan, mencintai, atau mengasihi, namun Allah akan selalu memperhatikan, memperdulikan, mencintai, dan mengasihinya. Apabila akidah semacam ini tertanam kuat di dalam diri seseorang, mentalnya akan kuat dan tangguh. la tidak lagi tergoda oleh perhatian, cinta kasih, dan kepedulian orang lain. Yang penting baginya adalah mendapat perhatian dan cinta kasih Allah SWT disertai dengan perbuatan-perbuatan positif yang ditampilkannya di tengah-tengah masyarakat atau lingkungannya. Direncanakan atau tidak, sikap dan perbuatan positif yang lahir dari perilakunya yang didasari oleh mental akidah islamiah tersebut, akan membawa pengaruh positif pula bagi dirinya. Perhatian, kasih sayang, dan kepedulian orang pun muncul dengan sendirinya, tanpa rekayasa. Bahkan kepedulian dan cinta kasih ini bersifat tulus dan murni.

Kedua, perasaan aman. Setiap orang membutuhkan rasa aman dalam dirinya, baik lahir maupun batin. Apabila perasaan aman ini tidak diperoleh seseorang, jiwa dan mentalnya akan terganggu. Jiwa yang terganggu dapat menimbulkan berbagai penyakit dan melahirkan tindakan negatif sebagaimana disebutkan di atas.

Dalam Islam diajarkan, alam semesta dengan segenap isinya adalah makhluk Allah yang selalu berada dalam pengawasan, pemeliharaan, dan pengetahuan-Nya. Allah akan memberikan perlindungan kepada hambahamba-Nya, terutama hamba yang bakti dan faat kepada-Nya. Akidah atau keyakinan seperti ini apabila tertanam kuat dalam jiwa seseorang, ia akan merasa aman dan selalu merasa dilindungi. Ia tidak akan takut menghadapi apapun dari siapa pun dan dalam bentuk apa pun. Dalam surat al-Quran surat al-Quraisy ayat 4, Allah berfirman yang artinya Allah memberikan makanan kepada mereka untuk menghilangkan rasa lapar dan mengamankan mereka dari ketakutan.

Ketiga, rasa harga diri. Setiap orang memiliki rasa harga diri dan ingin agar dirinya dihargai orang lain. Untuk mendapatkan penghargaan 
masyarakat tersebut ia berusaha menuruti dan menaati norma-norma sosial yang ada dalam lingkungannya, bahkan kalau mungkin ia berusaha mempengaruhi dan menguasainya. Setiap orang ingin harga dirinya terangkat, dipuji, tidak dilecehkan, direndahkan, apalagi dihinakan. Apabila rasa harga ini terganggu, jiwanya akan tergoncang, perasaan kecewa dan tidak senang menyerangnya, bahkan dapat menimbulkan dendam terhadap orang lain dan berusaha mencelakakan orang tersebut (Kartono, 2002:157).

Jika akidah atau keyakinan sebagaimana diajarkan Islam di atas tertanam dalam jiwa seseorang, mentalnya akan kuat, mental tidak tergoncang hanya oleh karena orang lain tidak memberikan penghargaan kepadanya. la yakin, Allah memuliakan dan menghargainya. Buktinya, Allah selalu berikan rezeki padanya. Apalagi kalau ia bertakwa kepada Allah, ia yakin derajatnya di sisi Allah semakin tinggi. Karena itu, yang penting baginya, bukan berharap penghargaan dan penghormatan orang lain, tapi penghormatan dan penghargaan dari Allah. Untuk itu, ia berusaha secara maksimal bertakwa kepada Allah SWT. Hasilnya, bukan saja jiwanya tenang, tapi juga penghargaan dari manusia pun ia peroleh.

Keempat, rasa ingin tahu atau mengenal sesuatu. Setiap orang mempunyai naluri ingin tahu. Ini memang sifat manusia. Kemajuan ilmu pengetahuan dan teknologi dewasa ini merupakan wujud dari rasa ingin tahu manusia. Perkembangan kebudayaan dan peradaban juga tidak lepas rasa ingin tahu manusia itu yang terwujud dalam bentuk kemajuan kebudayaan dan peradaban tersebut. Manusia berusaha keras menembus ruang angkasa, menjelajahi bulan, dan berusaha menjangkau planetplanet, semuanya karena ingin tahu. Keingintahuan seseorang terhadap sesuatu kadang-kadang tidak terbatas, bahkan ada yang menginginkan sesuatu yang tidak mungkin diketahuinya atau tidak mungkin dicapai oleh kemampuannya. Ingin tahu yang tak terbatas inilah yang dapat merugikan dirinya, bahkan orang lain. Orang lain bisa menjadi korban dari 
berbagai percobaan yang dilakukannya dalam usaha untuk mengetahui sesuatu, atau dirinya sendiri menjadi stress berat karena ia tidak berhasil mengetahui obyek yang dikaji dan dicobanya tersebut.

Orang yang memiliki akidah Islamiah akan sadar bahwa obyek yang bisa diketahui manusia terbatas, sebab manusia adalah ciptaan Tuhan yang diciptakan dengan segala keterbatasannya. Dengan keterbatasan itu, kemampuan otak manusia pun terbatas. Tidak semua yang ada dapat diketahui oleh manusia, sekalipun ilmu pengetahuan itu selalu berkembang.

Dengan keyakinan bahwa kemampuan manusia terbatas, yang bisa diketahui manusia terbatas, seorang Muslim tidak akan terjerumus kepada stres berat dan melakukan tindakan yang merugikan dirinya sendiri atau orang lain. la bisa bebas dari tekanan mental keingintahuan yang menggebu-gebu, tanpa harus menjadi apatis dan statis.

Kelima, rasa ingin sukses. Setiap orang ingin sukses dalam kehidupannya sebab kesuksesan itu akan membawa kebahagiaan. Makin banyak sukses yang dicapai, makin bertambah rasa kepuasan yang dirasakan seseorang. Akan tetapi, apabila terjadi sebaliknya, kegagalan, batinnya akan mengalami ketegangan dan kegoncangan. Ketegangan yang terus menerus terjadi akan mengakibatkan timbulnya berbagai penyakit, baik lahir maupun batin. Ketegangan, apalagi stress berkepanjangan, tidak akan terjadi pada manusia yang memiliki akidah Islamiah yang kuat karena dengan keyakinannya yang kokoh akan adanya Allah, kekuasaan, bantuan, dan pertolongan-Nya, ia bisa tenang menghadapi setiap kegagalan.

Dariuraian diatas dapat ditegaskanbahwakehidupanjiwa seseorang merupakan barometer dari kesehatan jasmaninya. Obat yang paling mujarab untuk membasmi basil-basil gangguan mental adalah suntikan imunitas keimanan (tauhid) kepada Allah dan mempraktekkannya dalam sikap hidup sehari-hari dengan baik dan benar. 
Dengan mengkalkulasi nikmat dan nilainya yang diberikan Allah, bersyukur, dan berdoa kepada-Nya, seseorang akan sadar bahwa Tuhan mencintai dan mengasihinya. Tuhan tidak membiarkannya sendiri. Tuhan selalu memberinya nikmat dan nikmat itu sangat banyak. Tak seorang manusia pun yang mampu menghitung berapa banyak nikmat yang diberikan Tuhan itu. Dengan kesadaran ini, jiwa seseorang akan tenang, tenteram dan damai. Ia terbebas dari stress dan ketegangan jiwa.

Oleh sebab itu dengan senantiasa bertauhid yang kuat dan benar maka jiwa seseorang akan senantiasa sehat karena ia senantiasa dapat menyesuaikan diri, bersifat qona'ah atau merasa cukup apa yang diterima, terhindar dari rasa gelisah takut ia hidup selalu penuh dengan harapan atau optimis tanpa ada rasa sikap putus asa. Hal ini sesuai dengan rumusan kriteria jiwa yang sehat yang telah dirumuskan dalam sidang umum WHO pada tahuin 1959 di Geneva yaitu; (a) Dapat menyesuaikan diri secara konstruktif pada kenyataan, meskipun kenyataan itu buruk baginya. (b) Memperoleh kepuasan dari hasil jerih payah usahanya. (c) Merasa lebih puas memberi daripada menerima. (d) Secara relatif bebas dari rasa tegang (stres, cemas dan depresi). (e) Berhubungan dengan orang lain secara tolong menolong dan saling memuaskan.

Dengan demikian uaraian di atas menunjukkan bahwa ada relasi yang kuat antara bertauhid dengan kesehatan mental, karena dengan tauhid mental seseorang dapat berkembang sesuai dengan tuntunan Allah SWT yang tidak perlu lagi diragukan akan kebenaran dari semua petunjuknya yang ada dalam al-Quran.

\section{Simpulan}

Peranan tauhid sangat penting dalam memelihara dan membentuk kesehatan mental seseorang. Tauhid dengan rukun iman yang berjumlah enam saling berhubungan. Bila seseorang menjalankan dan menyakini serta menghayati rukun iman yang berjumlah enam sangat mustahil 
mentalnya terganggu. Justru sebaliknya orang yang beriman bisa dipastikan memiliki mental yang sehat. Orang yang beriman kepada rukun iman yang berjumlah enam itu dengan sangat yakin serta penghayatan yang dalam maka bukan tidak mungkin bahkan merupakan kepastian bahwa mentalnya akan senantiasa sehat. Kesehatan mental jika diimplementasikan dalam bentuk yang konkrit maka ada relevansinya dengan bimbingan dan konseling Islam. Dengan demikian dapat sesuai tujuan bimbingan dan konseling Islami yaitu membantu individu atau klien yang sedang terkena masalah atau belum terkena masalah untuk menjadi manusia seutuhnya dan bertakwa kepada Tuhan menuju kebahagian hidup di dunia dan akhirat.

\section{Daftar Pustaka}

Abduh, Syeikh Muhammad. 1979. Risalah Tauhid. Jakarta: Bulan Bintang. Ahmadi, Abu \& Ahmad Rohani. 1991. Bimbingan dan Konseling di Sekolah. Jakarta: Rineka Cipta.

Ahyadi, 1995. Psikologi Agama; kepribadian Muslim Pancasila. Bandung: Sinar Baru

Albertin, Andrea and P. K. R. Nair. (2004). Farmers perspectives on the role of shade trees in coffee production systems: an assessment from the Nicoya Peninsula, Costa Rica: Human Ecology.

Al-Faruqi, Ismail. Christian Ethics; A Historycal and Systematic Analysis of its Dominant Idea, Montreal. Amsterdam: McGill University Press

Bastaman, Hanna Djumhana. 1997. Integrasi Psikologi dengan Islam Menuju Psikologi Islami. Yogjakarta: Pustaka Pelajar.

Daradjat, Zakiyah. 1990. Kesehatan Mental. Jakarta: Gunung Agung. Hawari, Dadang. 2002. Dimensi Religi Dalam Praktek Psikiatri dan Psikologi. Jakarta: Fakultas Kedokteran Universitas Indonesia.

Kartono, Kartini. 1989. Hygiene Mental dan Kesehatan Mental dalam Islam. Bandung: Mandar Maju. 
INJECT: Interdisciplinary Journal of Communication, Vol.1, No.1, Juni 2016: h. 1-24

Kridaklasana. 1989. Pembentukan Kata dalam Bahasa Indonesia. Jakarta: Gramedia.

Langgulung, Hasan. 1986. Teori-Teori Kesehatan Mental. Jakarta: Pustaka AlHusna.

Lusikooy, W. 1983. Bimbingan dan Penyuluhan di Perguruan Tinggi. Jakarta: Gunung Agung

Maududi, Abul ala. 1974. Political Theory of Islam. Lahore: Islamic Publications.

Musnamar, Tohari. 1992. Dasar-dasar Konseptual Bimbingan dan Konseling Islami. Yogyakarta: UII Press.

Priyatno dan Anti. 1993. Dasar-Dasar Bimbingan dan Konseling. Jakarta: Rineka Cipta

Rakhmat, Jalaluddin, 2004. Metode Penelitian Komunikasi. Bandung: Remaja Rosdakarya

Ramayulis. 2002. Ilmu Pendidikan Islam. Jakarta: Kalam Mulia.

Razak, Nasruddin. 1989. Dienul Islam. Bandung: Alma`arif

Sukardi, Dewa Ketut. 1983.Dasar-dasarBimbingandanPenyuluhandiSekolah. Surabaya: Usaha Nasional.

Syafiq A, Mughni. 2001. Nilai-nilai Islam: Perumusan Ajaran dan Upaya Aktualisasi. Yogyakarta: Pustaka Pelajar.

Walgito, Bimo. 1981. Pengantar Psikologi Umum. Yogyakarta: Fakultas Psikologi UGM

Winkel, WS. 1991. Bimbingan dan Konseling di Institusi Pendidikan. Jakarta: Grasindo. 